\title{
Excessive glucose production, rather than insulin resistance, accounts for hyperglycaemia in recent-onset streptozotocin- diabetic rats
}

\author{
R. Burcelin ${ }^{1,2}$, M. Eddouks' ${ }^{1}$ J. Maury ${ }^{2}$, J. Kande ${ }^{2}$, R. Assan 1 , J. Girard ${ }^{2}$ \\ ${ }^{1}$ Service de Diabétologie Hôpital Bichat, Paris, France \\ ${ }^{2}$ Centre de Recherche sur l'Endocrinologie Moléculaire et le Développement du CNRS, Meudon, France
}

\begin{abstract}
Summary Glucose production and utilization and activities of key enzymes involved in liver and muscle glucose metabolism were studied in post-absorptive streptozotocin-diabetic rats after $12 \mathrm{~h}$ of severe hyperglycaemia $(17.5 \pm 0.5 \mathrm{mmol} / \mathrm{l})$ and insulinopenia $(5 \pm 1 \mu \mathrm{U} / \mathrm{ml})$. Basal glucose production was increased: $36.6 \pm 3.0 \mathrm{mg} \cdot \mathrm{kg} \cdot \mathrm{min}^{-1}$, vs $24.4 \pm 2.5$ in controls $(p<0.05)$; liver glycogen concentration was decreased by $40 \%(p<0.05)$; liver phosphoenolpyruvate carboxykinase and glucose-6-phosphatase activities were increased by 375 and $156 \%$, respectively $(p<0.001$ and $<0.01)$. During a euglycaemic clamp at a plasma insulin level of $200 \mu \mathrm{U} / \mathrm{ml}$, glucose production was totally suppressed in controls, but persisted at $20 \%$ of basal in diabetic rats. In these rats, glucose production was suppressed at a plasma insulin level of $2500 \mu \mathrm{U} / \mathrm{ml}$. Basal whole body glucose utilization rate, 2-deoxy-1-[ $\left[{ }^{3} \mathrm{H}\right]$-D-glucose $\left(\left[{ }^{3} \mathrm{H}\right]-2 \mathrm{DG}\right)$ uptake by muscles and muscle glycogen concentrations were similar in both groups, as well as total and active forms of pyruvate dehydrogenase and glyco-
\end{abstract}

gen synthase activities. During the euglycaemic clamp, the total body glucose utilization rates and $\left[{ }^{3} \mathrm{H}\right]-2 \mathrm{DG}$ uptake by muscles were similar in control and diabetic rats at a plasma insulin level of $200 \mu \mathrm{U} /$ $\mathrm{ml}$, but lower in diabetic rats at a plasma insulin level of $2500 \mu \mathrm{U} / \mathrm{ml}$. We conclude 1 ) in recent-onset severely insulinopenic rats, an excessive glucose production via gluconeogenesis prevailed, mainly accounting for the concomitant hyperglycaemia. This excess glucose output cannot be attributed to liver insulin resistance: the gluconeogenic pathway is physiologically less sensitive than glycogenolysis to the inhibition by insulin. 2) Glucose utilization was apparently normal under hyperglycaemic conditions and at a lower insulin plateau of the euglycaemic clamp but suboptimal in the presence of maximal insulin concentrations, suggesting an early appearance of peripheral insulin resistance. [Diabetologia (1995) 38:283-290]

Key words Streptozotocin, insulinopenic diabetes, glucose turnover, gluconeogenesis, insulin resistance
Insulin action is defective in established human insulin-dependent diabetes mellitus (IDDM) and in its animal models [1-3]. It is now acknowledged that

Received: 15 January 1994 and in revised form: 12 September 1994

Corresponding author: Professor R. Assan, Service de Diabetologie, Hôpital Bichat, 46 rue Huchard, F-75877 Paris, Cedex 18, France

Abbreviations: STZ, streptozotocin; IDDM, insulin-dependent diabetes mellitus; PEPCK, phosphoenolpyruvate carboxykinase; $\mathrm{PDH}$, pyruvate dehydrogenase; G6Pase, glucose 6phosphatase; NEFA, non-esterified fatty acids; DCA, sodium dichloroacetate. when beta-cell destruction is the primary cause of hyperglycaemia, insulin resistance develops secondarily [4]. Both glucose overproduction and underutilization then contribute to the pathophysiology of hyperglycaemia. At the earliest stage of acute insulin deficiency, the chronology of insulin resistance and its potentially uneven distribution and progression in various insulin-sensitive tissues are still a matter of discussion. Recent-onset IDDM patients studied after a few days of insulin therapy are markedly insulin resistant $[5,6]$. Spontaneously diabetic BB rats, studied $24 \mathrm{~h}$ after detection of hyperglycaemia, are resistant to insulin, despite normal insulin sensitivity on the previous day [7]. In well-defined streptozoto- 
cin (STZ) diabetic rats, insulin resistance was detected $48 \mathrm{~h}$ or more after the STZ injection, affecting both glucose production and glucose utilization [812].

The present study was designed to clarify the following: 1) what appears first at the earliest stage of STZ-induced insulinopenic diabetes in rats: excessive glucose production by the liver, or decreased glucose utilization by insulin-sensitive tissues? 2) if present, how does resistance to insulin affect the different target tissues ? To this end, unstressed, freely-moving rats, well defined from a metabolic standpoint, were subjected to a euglycaemic hyperinsulinaemic clamp $30 \mathrm{~h}$ after STZ treatment, i. e. after $12 \mathrm{~h}$ of insulinopenia; total body glucose turnover, glucose utilization by muscles and adipose tissues were determined as well as liver and skeletal muscle glycogen levels, and the activities of key enzymes of glucose metabolism in the post-absorptive state: phosphoenolpyruvate carboxykinase (PEPCK) and glucose 6-phosphatase (G 6-Pase) in the liver; glycogen synthase and pyruvate dehydrogenase $(\mathrm{PDH})$ in muscle.

\section{Materials and methods}

Animals. Syngeneic male Wistar rats (IFFA Credo, L'Arbresle, France) were purchased at a body weight of 180-200 g, housed at $24^{\circ} \mathrm{C}$, with lights on from 07.00 to 19.00 hours, and free access to water and chow pellets (Extra-labo, Paris, France) $(\%$ of energy: carbohydrate $65 \%$, fat $11 \%$, protein $24 \%$ ). At a weight of about $250 \mathrm{~g}$, they were randomly assigned to either the control or STZ-diabetes groups.

Surgical procedures. In order to serially follow the circulating substrate and hormone levels in unstressed conscious rats, indwelling vascular catheters (internal diameter 0.025 in, outer diameter 0.048 inches, Silastic, Dow Corning Co, Midland, Mich., USA) were implanted $24 \mathrm{~h}$ before the experiments. Rats were anaesthetized with thiopental $(50 \mathrm{mg} / \mathrm{kg}$ body weight, IP). The two catheters were implanted into the two jugular veins, filled with heparin solution $(20 \mathrm{U} / \mathrm{ml})$, sealed, tunnelled subcutaneously to the back of the neck, externalized through a skin incision and anchored to the skull with a dental cement cap (Pennwalt, Philadelphia, Pa., USA). Care was taken to drive catheters at two different levels: the right cardiac cavities for the sampling catheter, and the upper part of the left jugular vein for the infusion catheter. Contamination of the samples by infusion fluids, which could result in some artefactual overestimation of the $\left[3^{3} \mathrm{H}\right]$ glucose enrichment and underestimation of the hepatic glucose production, was thus minimized. Immediately after surgery, rats were housed in individual metabolic cages. They were conscious, undisturbed and unrestrained before and during the study. The recovery after surgery was rapid. Food intake during the night preceding clamp experiments was $15-18 \mathrm{~g}$ in control rats and $18-20 \mathrm{~g}$ in STZ-diabetic rats. Body weight before starting clamp experiments was $95-100 \%$ of pre-operative weight in controls, and $85-95 \%$ in STZ-diabetic rats. Control rats were surgically operated, sham-injected and subjected to the same metabolic investigations as STZ-diabetic rats.

Diabetes induction. Destruction of pancreatic beta-cells was performed by a single i.v. injection of STZ $(65 \mathrm{mg} / \mathrm{kg}$ body wt), $24 \mathrm{~h}$ after catheter implantation. Streptozotocin (Sigma, St Louis, Mo., USA) was dissolved extemporaneously in 0.1 mol/l cold sodium citrate, $\mathrm{pH} 4.5$. To determine the exact time of onset of hyperglycaemia, venous blood glucose levels were measured every $2 \mathrm{~h}$ after the STZ injection, using glucose-oxidase strips (Glucostix; Ames, Elkhart, Ind., USA), read with a reflectance meter (Glucometer II, Ames). The changes in blood metabolites were also analysed up to $72 \mathrm{~h}$ in similar STZ-diabetic rats not subjected to clamp experiments.

The time selected for clamp experiments allowed minimization of metabolic and hormonal interferences due to early stress and acute blood glucose variations for the first hours and, later, those due to prolonged hyperglycaemia, excessive plasma non-esterified fatty acid (NEFA) levels among others. Owing to the chronically implanted catheters and the careful follow-up after STZ injection, the rats were metabolically homogeneous, unstressed, awake and freely moving, and had active postural muscles, thus allowing a valid interpretation of glucose turnover data.

\section{Glucose homeostasis in the post-absorptive state}

Glucose turnover. Experiments were started $30 \mathrm{~h}$ after STZ injection, i.e. $12 \mathrm{~h}$ after the onset of significant hyperglycaemia $(7.2 \pm 0.5 \mathrm{mmol} / \mathrm{l})$. Food was withdrawn at 7.00 hours and the experiments were started at 14.00 hours. Under these conditions, blood glucose concentrations were not higher in the portal vein than in the aorta: $17.2 \pm 1.9 \mathrm{mmol} / 1$ and $16.9 \pm 1.5$ $\mathrm{mmol} / \mathrm{l}$, respectively [11], indicating that the gut did not add significant amounts of glucose into the portal circulation from previously ingested food. The rats were thus considered to be in the post-absorptive state, the rate of glucose production was therefore a measure of endogenous glucose formation. Urine was collected for quantification of urinary glucose loss and for measurement of $\left[3{ }^{3} \mathrm{H}\right]$ glucose specific activity [13].

Basal glucose turnover was quantified using a bolus primed $(5 \mu \mathrm{Ci})$-continuous $(1 \mu \mathrm{Ci} / \mathrm{min}) \mathrm{i}$. v. infusion of $\left[3-{ }^{3} \mathrm{H}\right]$ glucose (Amersham International, Amersham, Bucks, UK), which was maintained for $90 \mathrm{~min}$ in control rats $(n=5)$ and diabetic rats $(n=9)[14]$. Three samples were collected at $10-\mathrm{min}$ intervals for the last $20 \mathrm{~min}$ of the experimental period for measurement of glucose specific activity. It was verified that glucose specific activity was constant in these three samples. Rats in which glucose specific activity changed by more than $10 \%$ during the last $20 \mathrm{~min}$ were discarded.

Glucose utilization index in individual tissues. Glucose utilization index in individual tissues was assessed under basal conditions in six control and six hyperglycaemic STZ-diabetic rats, after an injection of a tracer amount $(30 \mu \mathrm{Ci})$ of the non-metabolizable glucose analogue 2-deoxy-1- $\left[{ }^{3} \mathrm{H}\right]$-D-glucose $\left(\left[{ }^{3} \mathrm{H}\right]\right.$ 2DG) (Centre de l'Energie Nucléaire, Saclay, France) in $300 \mu \mathrm{l}$ of saline. The slope of $\left[{ }^{3} \mathrm{H}\right]-2 \mathrm{DG}$ disappearance from plasma was calculated from samples collected at $1,3,7,10,20$, 30 and $60 \mathrm{~min}$ after $\left[{ }^{3} \mathrm{H}\right]-2 \mathrm{DG}$ injection; levels at $60 \mathrm{~min}$ were less than $10 \%$ of the 1 -min value [15]. One hour after $\left[{ }^{3} \mathrm{H}\right]$ $2 \mathrm{DG}$ administration, the different tissues were sampled for determination of 2-deoxy-1-[ $\left[{ }^{3} \mathrm{H}\right]-6$-phosphate $\left(\left[{ }^{3} \mathrm{H}\right]-2 \mathrm{DGP}\right)$ content [15].

At the end of the tests, $3 \mathrm{ml}$ of venous blood was collected on $200 \mu \mathrm{l}$ of a mixture of $2000 \mathrm{U} / \mathrm{ml}$ aprotinine (Iniprol, Laboratoires Choay, Paris, France) and $0.01 \mathrm{~mol} / \mathrm{l}$ EDTA and immediately centrifuged at $+4^{\circ} \mathrm{C}$. Plasma was frozen at $-20^{\circ} \mathrm{C}$ until determination of plasma insulin and glucose concentrations. Animals were then killed by an i.v. injection of thiopental $(60$ $\mathrm{mg} \cdot \mathrm{kg}^{-1} \cdot$ body weight $\left.{ }^{-1}\right)$. The following hindquarter muscles 
were rapidly removed (all within $2 \mathrm{~min}$ ): soleus (a slow twitch, oxidative muscle), extensor digitorum longus (a fast twitch, glycolytic muscle), diaphragm and heart ventricle. Epididymal and interscapular fat pads were also removed. All tissues were rapidly rinsed in chilled $0.9 \% \mathrm{NaCl}$ solution, frozen in liquid nitrogen and stored at $-80^{\circ} \mathrm{C}$ until analysis of $\left[{ }^{3} \mathrm{H}\right]-2 \mathrm{DGP}$ content [15].

Glycogen concentration and enzyme activities. Further control $(n=6)$ and diabetic $(n=6)$ rats were killed by cervical dislocation. Samples of the hepatic median lobe of the liver $(0.3 \mathrm{~g})$ and of soleus muscle were rapidly frozen and ground in liquid nitrogen for further determination of glycogen concentration. Enzyme activities were measured on fresh homogenates of liver and soleus muscles.

\section{Glucose homeostasis in the euglycaemic hyperinsulinaemic clamp}

Glucose turnover. In these experiments, the blood glucose concentration of STZ-diabetic rats was normalized (from 17.5 to $5.5 \mathrm{mmol} / \mathrm{l}$ ) within the first $30 \mathrm{~min}$ of the experimental period by a primed-continuous insulin infusion. Recent experiments in spontaneously diabetic BB rats have shown that normalization of blood glucose levels within $30 \mathrm{~min}$ by insulin infusion did not increase plasma glucagon and epinephrine plasma levels $[7,16]$. Thus, we assume that no counterregulation occurred in STZ-diabetic rats in these experimental conditions.

Two rates of insulin (Actrapid; Novo, Copenhagen, Denmark) infusions were used: 1) either a bolus of $16 \mathrm{mU} / \mathrm{kg}$ and then a continuous infusion at a rate of $0.8 \mathrm{U} \cdot \mathrm{kg}^{-1} \cdot \mathrm{h}^{-1}$ to obtain a lower plasma insulin steady-state of about $200 \mu \mathrm{U} / \mathrm{ml}$ for $90 \mathrm{~min}$ (control rats) and $120 \mathrm{~min}$ (diabetic rats), the 30 min difference being due to the time necessary for normalization of the blood glucose level in the diabetic rats; or 2) a bolus of $84 \mathrm{mU} / \mathrm{kg}$ and then a continuous infusion at a rate of 3.2 $\mathrm{U} \cdot \mathrm{kg}^{-1} \cdot \mathrm{h}^{-1}$ to obtain a higher plasma insulin steady-state of about $2500 \mu \mathrm{U} / \mathrm{ml}$. At $5-10 \mathrm{~min}$ intervals, a droplet $(20 \mu \mathrm{l})$ of venous blood was collected for glucose determination. The initial glucose infusion rate was adjusted manually to maintain the blood glucose level around $5.5 \mathrm{mmol} / \mathrm{l}$. Glucose turnover was quantified using the above described primed-continuous $\left[3-{ }^{3} \mathrm{H}\right]$ glucose infusion, which was maintained for $90 \mathrm{~min}$ in control and $120 \mathrm{~min}$ in STZ-diabetic rats. Three blood samples were collected at 10 -min intervals during the last 20 min of the experimental periods for measurement of glucose specific activity. Glucose turnover was quantified during euglycaemic hyperinsulinaemic clamp [14] in 19 control (lower steady-state plasma insulin: $n=10$; higher steady-state plasma insulin: $n=13$ ) and 23 diabetic rats (lower steady-state plasma insulin: $n=10$; higher steady-state plasma insulin: $n=10$ ).

Glucose utilization index in individual tissues. Glucose utilization index in individual tissues was quantified under clamp conditions in 12 control (lower steady-state plasma insulin: $n=6$; higher steady-state plasma insulin: $n=6$ ) and 12 normoglycaemic STZ-diabetic rats (lower steady-state plasma insulin: $n=6$; higher steady-state plasma insulin: $n=6$ ), after injection of a tracer amount of $\left[{ }^{3} \mathrm{H}\right]-2 \mathrm{DG}$, as described above. The glucose utilization index was measured during the last $60 \mathrm{~min}$ of euglycaemic hyperinsulinaemic clamps.

\section{Determinations}

Substrates and hormones. During clamp experiments, venous blood glucose was determined by the glucose oxidase method using a Beckman glucose analyzer (Beckman BGA2; Galway, Republic of Ireland). Plasma insulin and glucagon concentrations were determined by radioimmunoassay [17]. Insulin was assayed with a kit (Pharmacia, Uppsala, Sweden) including human insulin as standard, an ${ }^{125} \mathrm{~T}$-labelled human insulin tracer and a guinea-pig anti-human-insulin antibody, which cross-reacts similarly with rat insulin. The glucagon assay kit from Pharmacia includes porcine glucagon as standard, a porcine ${ }^{125}$ I-labelled glucagon tracer and a rabbit anti-porcine antiserum specific for pancreatic glucagon. NEFA were determined by an enzymic method using an acyl-CoA oxidase-based colourimetric kit (WAKO, NEFA-C, Wako Pure Chemical Industries, Osaka, Japan). Ketonuria was semi-quantitatively estimated by use of Ketodiastix strips (Ames).

Isotope determinations. For 2-deoxy-1-[3 $\mathrm{H}]$-D-glucose and [3$\left.{ }^{3} \mathrm{H}\right]$ glucose determinations, plasma samples were immediately deproteinized in $5.5 \% \mathrm{ZnSO}_{4}$ and saturated barium hydroxide-zinc sulphate mixture [15]. Glucose was determined in the supernatant by a glucose oxidase method. An aliquot was evaporated to dryness to eliminate tritiated water, and counted in a beta-scintillation counter (Beta-Matic, Kontron, Paris, France). Tissue $\left[{ }^{3} \mathrm{H}\right]-2 \mathrm{DGP}$ content was determined as previously described [15].

Urinary glucose excretion rate. In basal conditions, urinary $\left[{ }^{3} \mathrm{H}\right]$-glucose excretion rate in STZ-diabetic rats was obtained by pooling urine obtained by spontaneous micturition and urine obtained from the bladder at the time of killing [13].

During clamp experiments the urinary $\left[{ }^{3} \mathrm{H}\right]$-glucose excreted following the initial 30-min normalization of blood glucose concentration was measured and subtracted from the total urinary $\left[{ }^{3} \mathrm{H}\right]$-glucose excreted during the clamp, in order to obtain the net urinary glucose excretion rates under euglycaemic conditions [13].

Enzyme activities and glycogen. All enzyme activities were carried out at $37^{\circ} \mathrm{C}$. Phosphoenolpyruvate carboxykinase (PEP$\mathrm{CK}$ ) activity was determined using the $\mathrm{NaH}\left[{ }^{14} \mathrm{C}\right] \mathrm{O}_{3}$ fixation assay [17]. Results were expressed as nmol of $\mathrm{NaH}\left[{ }^{14} \mathrm{C}_{3} \mathrm{O}_{3}\right.$ fixed per min per milligram of protein. Glucose 6-phosphatase (G 6-Pase) activity was measured by determining the inorganic phosphate formed from Glucose 6-phosphate during a 10-min incubation [18]. A $300-\mathrm{mg}$ sample of the main liver lobe was ground in liquid nitrogen and homogenized in $10 \mathrm{ml}$ citrate buffer $(0.1 \mathrm{~mol} / \mathrm{l}, \mathrm{pH} 6.5)$. The homogenate was kept less than $30 \mathrm{~min}$ in ice before assay; $100 \mu \mathrm{l}$ was added to $100 \mu \mathrm{l}$ of glucose 6-phosphate $(0.08 \mathrm{~mol} / \mathrm{l})$ for $10-\mathrm{min}$ at $30^{\circ} \mathrm{C}$. The reaction was stopped by addition of $2 \mathrm{ml}$ trichloracetic acid (10\%). After a $10 \mathrm{~min}$ centrifugation at $4000 \mathrm{~g}, 0.5 \mathrm{ml}$ of the supernatant was mixed with the sulphomolybdic reagent, and the optical density was then compared to that of an inorganic phosphate standard tested in the same conditions. Glycogen synthase activity was measured as described by Rossetti et al. [18]. This assay is based on the incorporation of UDP$\left[\mathrm{U}^{-14} \mathrm{C}\right]$ glucose into glycogen. One of the two soleus muscles $(80 \mathrm{mg}$ ) was homogeneized in $2.0 \mathrm{ml}$ of Tris $/ \mathrm{HCl}$ buffer, $\mathrm{pH}$ 7.8 , containing $10 \mathrm{mmol} / 1 \mathrm{EDTA}, 5 \mathrm{mmol} / \mathrm{l}$ dithiothreitol, $50 \mathrm{mmol} / 1 \mathrm{NaF}$, and $2.5 \mathrm{~g} / \mathrm{l}$ rabbit liver glycogen type III. The homogenate was centrifuged at $2,000 \mathrm{~g}$ for $15 \mathrm{~min}$ at $4{ }^{\circ} \mathrm{C}$ and the supernatant used for glycogen synthase assay by measuring the incorporation of UDPG-[U $\left.-{ }^{14} \mathrm{C}\right]$ glucose into glycogen at $30^{\circ} \mathrm{C}$, in the presence of a physiologic concentration $(0.11 \mathrm{mmol} / \mathrm{l})$ of $\mathrm{G} 6 \mathrm{P}$. Total glycogen synthase activity was 


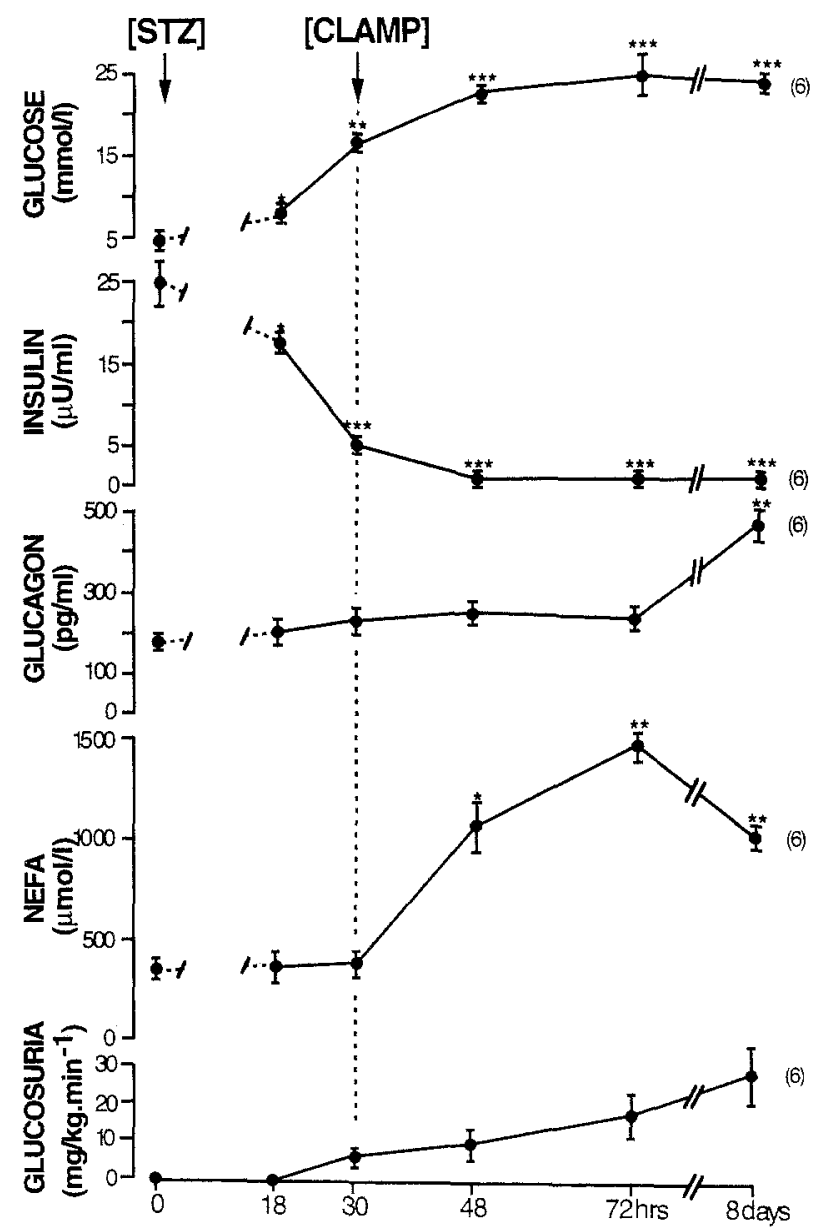

Fig. 1. Time-course of circulating substrate and hormone levels in STZ-treated rats. Results are presented as mean values \pm SEM. Numbers of animals are in parentheses. [STZ] arrow: time of streptozotocin injection. [clamp] arrow and the vertical dotted line: time of the clamp studies. ${ }^{*} p<0.05$; $* * p<0.01 ; * * * p<0.001$

measured in the presence of $7.2 \mathrm{mmol} / 1 \mathrm{G} 6-\mathrm{P}$ [18] and expressed as nmol of UDP-glucose incorporated into glycogen per min and per $\mathrm{mg}$ of protein. Pyruvate dehydrogenase (PDH) activity was measured in isolated mitochondria. Mitochondria from skeletal muscle were prepared extemporaneously and PDH activity immediately measured. Muscle (300 $\mathrm{mg}$ fresh tissue) was disrupted in sucrose buffer $(0.25 \mathrm{mmol} / \mathrm{l}$ sucrose $/ 5 \mathrm{mmol} / 1$ Tris-HCl$/ 2 \mathrm{mM}$ EGTA, $\mathrm{pH}$ 7.4) containing $50 \mathrm{mmol} / 1 \mathrm{NaF}$ and $10 \mathrm{mmol} / 1$ sodium dichloroacetate (DCA) as inhibitors of PDH kinase and PDH phosphatase. After differential centrifugation, mitochondria were divided into two portions. One was resuspended in $\mathrm{KCl}$ medium $(120 \mathrm{mmol} /$ 1:KCl/20 Tris-HCl/5 potassium phosphate/2 EGTA $\mathrm{pH} 7.4$ ) containing DCA and NaF, to inhibit the active/inactive enzyme interconversion, and then pelleted by centrifugation $(10,000 \times g)$, immediately frozen in liquid nitrogen and used for the determination of the PDH complex activity at the time of killing (PDHa). The other mitochondrial portion was washed of $\mathrm{NaF}$ and DCA by dilution (100 volumes of sucrose buffer free of inhibitors) and then pelleted by centrifugation. These mitochondria were then incubated for $30 \mathrm{~min}$ at $30^{\circ} \mathrm{C}$ in $\mathrm{KCl}$ medium containing $10 \mu \mathrm{mol} / 1 \mathrm{CCCP}$ (an uncoupler of oxidative phosphorylation) to obtain full reactivation of $\mathrm{PDH}$ by depleting mitochondrial ATP. Mitochondria were pelleted by centrifugation $(10,000 \times g)$, immediately frozen in liquid nitrogen and used for the determination of the total PDH activity (PDHt) (19].

Mitochondria were extracted in extraction buffer ( $50 \mathrm{mmol} / 1$ potassium phosphate $/ 10 \mathrm{mmol} / 1 \mathrm{EGTA} / 2 \mathrm{mmol} / \mathrm{l}$ dithiothreitol pH 7.0) for assay of enzyme and protein concentrations by alternate (three times) thawing $\left(30^{\circ} \mathrm{C}\right)$ and freezing in liquid nitrogen. Triton X100 was omitted from the extraction medium and added to the assay buffer in order to avoid interferences with protein determinations. The PDH complex activity in mitochondria extracts was assayed spectrophotometrically by coupling to arylamine acetyltransferase and following the production of acetyl CoA from pyruvate and CoA [20]. One unit of enzyme activity is defined as that which converts $1 \mu \mathrm{mol}$ of pyruvate into acetyl-CoA per min at $30^{\circ} \mathrm{C}$.

Protein concentration was determined by the method of Lowry using bovine serum albumin as a standard.

Glycogen and protein. Liver and muscle glycogen concentrations were measured according to Rossetti et al. [18]. This method is based on the hydrolysis of glycogen by amylo-1,41,6 glucosidase followed by determination of the glucose released by the glucose oxidase method. Protein concentration was determined using the Bio-Rad assay (Bio-Rad, Munich, Germany), with bovine serum albumin as standard.

Calculations. Glucose turnover was calculated by dividing the tracer infusion rate by the plasma glucose specific activity under steady-state conditions. In control rats (basal state), endogenous glucose production was considered equal to the rate of glucose appearance, glucose input from the digestive tract being negligible. In these rats glucose utilization equalled glucose production. During insulin infusions, glucose production was calculated by subtracting the steady-state glucose infusion rate from the glucose turnover rate to obtain glucose utilization values. The urinary glucose excretion rate was calculated by dividing the tracer infusion rate by $\left[{ }^{3} \mathbf{H}\right]$ glucose specific activity in urine. Glucose clearance was measured by dividing the glucose utilization rate by the plasma glucose concentration.

\section{Statistical analysis}

Results are presented as mean \pm SEM Statistical significance of differences was analysed by using Student's $t$-test for unpaired values.

\section{Results}

\section{Post-absorptive values}

Substrate and hormone concentrations. The STZ injection was followed by a transient phase of hyperinsulinaemia and hypoglycaemia, which was maximal at the sixth hour. Insulinopenia and hyperglycaemia developed progressively after the $18^{\text {th }}$ hour. At the $30^{\text {th }}$ hour after STZ injection (i.e. $12 \mathrm{~h}$ after the onset of hyperglycaemia), plasma insulin was $5 \pm 1 \mu \mathrm{U} / \mathrm{ml}$ and blood glucose $17.5 \pm 0.5 \mathrm{mmol} / \mathrm{l}$. All rats were glucosuric but not ketonuric. The peripheral plasma NEFA and glucagon levels were not significantly higher in diabetic than in control rats (Fig.1). The 
Table 1. Blood glucose and plasma insulin concentrations and glucose turnover rates in control and STZ-diabetic rats in the basal state and during euglycaemic hyperinsulinaemic clamp at low and high plasma insulin levels

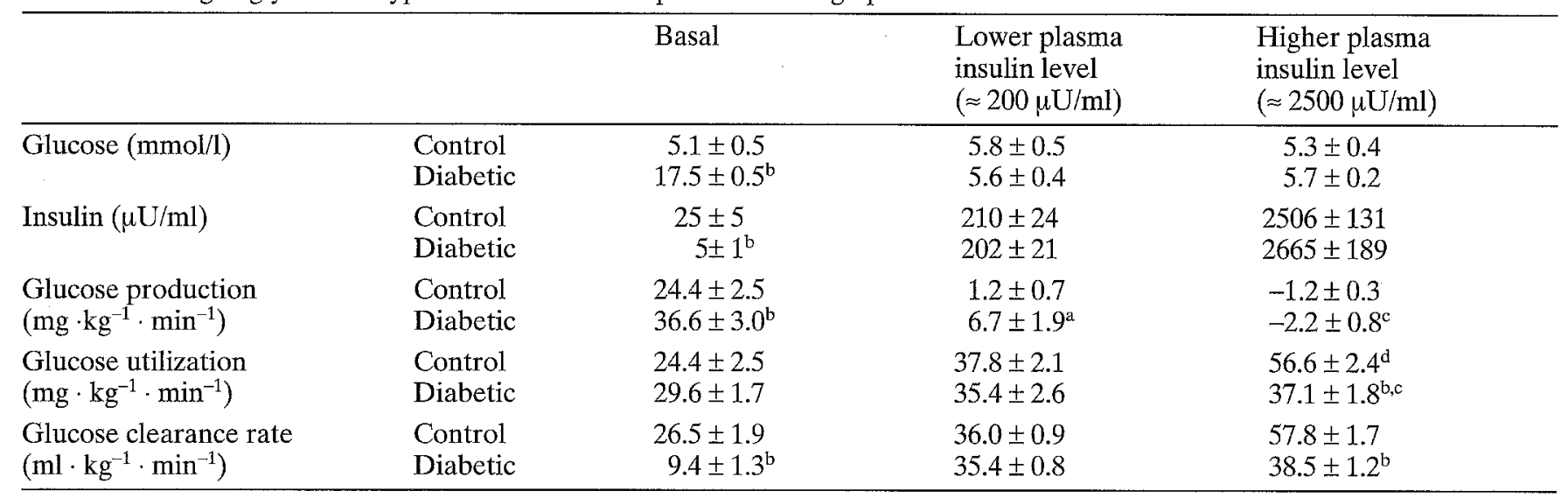

Results are mean values \pm SEM of 5 to 10 determinations in control rats and 9 to 13 determinations in diabetic rats

${ }^{\mathrm{a}} p<0.05 ;{ }^{\mathrm{b}} p<0.01$ from control rats (operated sham-injected rats)

diabetic rats lost $8.2 \%$ of their initial body weight over $30 \mathrm{~h}$, but kept normal motor activity. In similar STZ-diabetic rats, not subjected to the clamp studies, an 8-day follow-up demonstrated the persistence of severe insulinopenia, and a progressive rise in plasma glucagon and NEFA levels. Rats were ketonuric after the third day and none of them recovered from diabetes.

Glucose kinetics. In basal post-absorptive conditions, the endogenous glucose production rate was significantly higher in diabetic than in control rats: $36.6 \pm 3.0$ vs $24.4 \pm 2.5 \mathrm{mg} \cdot \mathrm{kg}^{-1} \cdot \mathrm{min}^{-1}, p<0.01$. The basal post-absorptive glucose utilization rate was similar in hyperglycaemic diabetic and in normoglycaemic control rats: $29.6 \pm 1.7 \mathrm{mg} \cdot \mathrm{kg}^{-1} \cdot \mathrm{min}^{-1}$ vs $24.4 \pm 2.5 \mathrm{mg} \cdot \mathrm{kg}^{-1} \cdot \mathrm{min}^{-1}$ (Table 1 ). These relatively high rates are consistent with the muscular activity in awake rats. The urinary glucose excretion rate was $6.7 \pm 2.7 \mathrm{mg} \cdot \mathrm{kg}^{-1} \cdot \mathrm{min}^{-1}$ in hyperglycaemic post-absorptive diabetic rats. The glucose clearance rate, an index of the capacity for glucose utilization independently of plasma glucose concentration, was decreased by $50 \%$ in diabetic rats: $9.4 \pm 1.3 \mathrm{mg}$. $\mathrm{kg}^{-1} \cdot \min ^{-1}$ vs $26.5 \pm 1.9 \mathrm{mg} \cdot \mathrm{kg}^{-1} \cdot \mathrm{min}^{-1}$ (Table 1 ).

Euglycaemic clamp. Normoglycaemia was reached $30 \mathrm{~min}$ after the start of insulin infusion in diabetic rats during the clamp experiments and blood glucose levels then remained steady and in the normal range until the end of the experiments. During the last 60 min of the clamps, urinary glucose excretion was negligible in all diabetic rats $(0.9 \pm 0.3 \mathrm{mg}$. $\left.\mathrm{kg}^{-1} \cdot \mathrm{min}^{-1}\right)$. At the lower insulin infusion rate, plasma insulin concentrations were close to $200 \mu \mathrm{U} / \mathrm{ml}$. At the higher infusion rate, plasma insulin concentrations were close to $2500 \mu \mathrm{U} / \mathrm{ml}$. Glucose production
${ }^{\mathrm{c}} p<0.05 ;{ }^{\mathrm{d}} p<0.01$ between glucose production and utilization at the lower and higher insulin plateau

was totally suppressed at plasma insulin levels of $200 \mu \mathrm{U} / \mathrm{ml}$ in control rats, whereas a significant glucose production persisted in diabetic rats $(6.7 \pm 1.9$ $\mathrm{mg} \cdot \mathrm{kg}^{-1} \cdot \mathrm{min}^{-1}$, i.e. $20 \%$ of basal glucose production). Glucose production was also totally suppressed in diabetic rats at plasma insulin levels of $2500 \mu \mathrm{U} / \mathrm{ml}$. The glucose utilization rate was increased to a similar extent at plasma insulin levels of $200 \mu \mathrm{U} / \mathrm{ml}$ in control and diabetic rats. However, maximal glucose utilization was significantly lower in diabetic than in control rats at plasma insulin levels of $2500 \mu \mathrm{U} / \mathrm{ml}$ (Table 1 ).

Glucose utilization in skeletal muscles and adipose tissues. In basal conditions, glucose utilization indices in skeletal muscles, heart and adipose tissues were similar in normoglycaemic control and hyperglycaemic diabetic rats (Table 2).

In clamp experiments at plasma insulin levels of $200 \mu \mathrm{U} / \mathrm{ml}$, insulin resistance was detected in some tissues (diaphragm, white and brown adipose tissues) of normoglycaemic diabetic rats but not in other tissues (heart, soleus, extensor digitorum longus). In contrast, a significant insulin resistance was detected in all tissues of normoglycaemic diabetic rats at plasma insulin levels of $2500 \mu \mathrm{U} / \mathrm{ml}$, i. e. under the conditions of maximal insulin effect (Table 2).

Glycogen concentration and enzyme activities in liver and muscles. Liver glycogen concentrations were significantly lower in post-absorptive diabetic than in control rats: $10.5 \pm 0.5$ vs $18.2 \pm 0.8 \mathrm{mg} / \mathrm{g}$ wet tissue $(p<0.05)$. Glycogen concentrations in non-operated fed adult rats were $30 \mathrm{mg} / \mathrm{g}$. The cytosolic PEPCK and $\mathrm{G}$ 6-Pase activities were markedly increased in liver of diabetic rats. PEPCK activity was $30.8 \pm 4.0$ in diabetic rats vs $8.2 \pm 0.8 \mathrm{mg} \cdot \mathrm{kg}^{-1} \cdot \mathrm{min}^{-1}(p<0.001)$ 
Table 2. Tissue glucose utilization $\left(\mathrm{ng} \cdot \mathrm{mg}^{-1} \cdot \mathrm{min}^{-1}\right.$ ) in control and STZ-diabetic rats during euglycaemic hyperinsulinaemic clamps at low and high plasma insulin levels

\begin{tabular}{lllll}
\hline Tissues & & Basal & $\begin{array}{l}\text { Lower plasma } \\
\text { insulin level } \\
250(\mu \mathrm{U} / \mathrm{ml})\end{array}$ & $\begin{array}{l}\text { Higher plasma } \\
\text { insulin level } \\
(2500 \mu \mathrm{U} / \mathrm{ml})\end{array}$ \\
\hline Diaphragm & & $22.3 \pm 2.4$ & $34.2 \pm 1.3$ \\
& Control & $4.5 \pm 0.8$ & $16.4 \pm 1.8^{\mathrm{a}}$ & $18.9 \pm 1.7^{\mathrm{b}}$ \\
Heart & Diabetic & $5.7 \pm 1.3$ & $17.3 \pm 1.2$ & $36.5 \pm 6.0$ \\
& Control & $6.9 \pm 0.8$ & $17.1 \pm 2.2$ & $17.7 \pm 3.1^{\mathrm{b}}$ \\
Soleus & Diabetic & $9.0 \pm 1.1$ & $17.3 \pm 3.8$ & $26.2 \pm 6.4$ \\
Extensor digitorum longus & Control & $5.4 \pm 0.6$ & $12.9 \pm 1.5$ & $13.6 \pm 0.1^{\mathrm{b}}$ \\
& Diabetic & $4.2 \pm 1.1$ & $6.4 \pm 0.9$ & $19.8 \pm 3.2$ \\
White adipose tissue & Control & $3.6 \pm 0.6$ & $5.0 \pm 0.8$ & $5.2 \pm 0.2^{\mathrm{b}}$ \\
& Diabetic & $5.1 \pm 0.7$ & $2.1 \pm 0.3$ & $2.9 \pm 0.5$ \\
Brown adipose tissue & Control & $0.5 \pm 0.1$ & $1.1 \pm 0.1^{\mathrm{a}}$ & $1.4 \pm 0.3^{\mathrm{b}}$ \\
& Diabetic & $0.4 \pm 0.1$ & $79 \pm 11$ & $130 \pm 14$ \\
& Control & $4.4 \pm 0.2$ & $47 \pm 9^{\mathrm{a}}$ & $69 \pm 6^{\mathrm{b}}$ \\
\hline
\end{tabular}

Results are means \pm SEM of six different rats in each group.

${ }^{\mathrm{a}} p<0.05^{\mathrm{b}} p<0.01$ from control rats

in control rats and $\mathrm{G} 6$-Pase activity was $7.3 \pm 0.3$ in diabetic rats vs $4.8 \pm 0.8 \mu \mathrm{mg} \cdot \mathrm{kg}^{-1} \cdot \mathrm{min}^{-1}$ in control rats $(p<0.05)$.

Glycogen concentrations in soleus muscles were similar in control and STZ-diabetic rats: $14.6 \pm 0.7$ and $13.9 \pm 0.6 \mathrm{mg} / \mathrm{g}$ wet tissue, respectively. The total PDH activity was also similar in both groups: $46 \pm 10$ $\mathrm{U} / \mathrm{mg}$ protein ( $54 \%$ in the active form) in the diabetic rats vs $50 \pm 10 \mathrm{U} / \mathrm{mg}$ ( $56 \%$ in the active form) in control rats. The total glycogen synthase activity was also similar: $5.4 \pm 0.3 \mathrm{mg} \cdot \mathrm{kg}^{-1} \cdot \mathrm{min}^{-1}(67 \%$ in the active form) in diabetic rats, vs $5.7 \pm 0.2 \mathrm{mg} \cdot \mathrm{kg}^{-1} \cdot \mathrm{min}^{-1}$ (56\% in the active form) in control rats.

\section{Discussion}

Recent-onset insulinopenia in STZ-diabetic rats was associated with glucose overproduction in the basal (hyperglycaemic) state. Under euglycaemic hyperinsulinaemic conditions, glucose overproduction was not fully suppressed at a plasma insulin level of $200 \mu \mathrm{U} / \mathrm{ml}$ (in contrast to control rats), but was entirely suppressed at plasma insulin levels of $2500 \mu \mathrm{U} /$ $\mathrm{ml}$. The liver glycogen concentrations were relatively low in all post-absorptive rats, presumably due to recent surgery and the 8-h fast; nevertheless liver glycogen concentrations were significantly lower in diabetic than in control rats. This was probably due to the insulin-deficient state of diabetic rats. However, a direct glycogenolytic effect of STZ on the liver cannot be excluded. Thus, it is unlikely that sustained glucose overproduction in post-absorptive diabetic rats originates from their limited liver glycogen stores. It is more likely that sustained glucose overproduction in post-absorptive diabetic rats originates from an increased hepatic gluconeogenesis as suggested by the increases in PEPCK and G 6-Pase activities in liver of recent-onset diabetic rats. An increase in gluconeogenesis [21-23) and in the activities of PEPCK $[24,25]$ and G-6-Pase [26, 27] has already been reported in the liver of fed, long-term diabetic rats while hormone-stimulated glycogenolysis was decreased [28]. In the present study, insulinopenia could have played a determinant role in these phenomena, in association with the mild concomitant hyperglucagonaemia $[25,26]$. The incomplete suppression of glucose production at plasma insulin levels of $200 \mu \mathrm{U} / \mathrm{ml}$ in euglycaemic clamps in recentonset diabetic rats does not necessarily indicate the presence of a state of liver insulin resistance. Indeed, it is well known that gluconeogenesis is significantly less sensitive to the inhibitory effect of insulin than glycogenolysis [29-31]. As gluconeogenesis is responsible for a larger proportion of liver glucose production in diabetic than in control rats, the incomplete suppression of glucose production at plasma insulin levels of $200 \mu \mathrm{U} / \mathrm{ml}$ could be due to the increase in gluconeogenesis rather than to a state of insulin resistance. It must be stressed, however, that we did not specifically measure the sensitivity of gluconeogenesis to insulin in these diabetic rats.

The glucose utilization rate in basal conditions was normal in diabetic rats, owing to the concomitant hyperglycaemia. Indeed, hyperglycaemia increases whole-body glucose utilization, independent of the prevailing insulin level $[31,32]$. However, as glucose clearance, an index of the capacity for glucose utilization independently of plasma glucose concentration, was decreased in diabetic rats, this indicated that the capacity for glucose utilization was already reduced, due to the state of insulinopenia. Insulin resistance was also detectable in different tissues during the euglycaemic hyperinsulinaemic clamp. In adipose tis- 
sue, insulin resistance was already significant at plasma insulin levels of $200 \mu \mathrm{U} / \mathrm{ml}$, which underlined the exquisite sensitivity of adipose tissue to insulin. Whole body and muscle insulin resistance were detectable only at plasma insulin levels of $2500 \mu \mathrm{U} / \mathrm{ml}$. The mechanisms responsible for the decrease in maximal insulin effects on muscles and adipose tissues in diabetic rats are still unclear. Neither insulin receptor numbers nor their state of phosphorylation have been reported to be affected in muscle and adipose tissue of diabetic rats $[33,34]$. We have previously reported that the expression of Glut- 4 and the activity of hexokinase HKII were unaltered in muscles of recent-onset diabetic rats [35]. The insulin-stimulated phosphorylation of insulin receptor substrate (IRS)1 and the activation of phosphatidylinositol (PI) 3-kinase are increased, not decreased, in muscle from STZ-diabetic rats [36-38]. Thus the defect in insulin action seems to be located at a step distal to the insulin receptor activation.

A defect in insulin-induced activation of the glycogen synthase, resulting in lower glycogen synthesis in muscles, could be the predominant cause of insulin resistance. Indeed, insulin increases the percentage of active form of glycogen synthase in skeletal muscle, whereas total activity remains unchanged [39-42].

In the present study, the total activity of glycogen synthase and PDH and the percent of their active forms were normal in the post-absorptive state, indicating that recent-onset diabetes does not induce a decrease in the synthesis of these two proteins. Unfortunately, the phosphorylation state of glycogen synthase and PDH (active forms) in muscles of diabetic rats was not assessed at the end of clamp experiments. The most likely explanation for the early defect in maximal insulin-stimulated glucose utilization observed in the present study, would be a decrease in insulin-stimulated phosphorylation state of glycogen synthase and PDH (active forms) in muscles of diabetic rats. This needs to be determined in further experiments.

Acknowledgements. We thank Professor E. Cerasi and Drs. L. Rossetti and E. Larger for helpful discussion and revision of the manuscript. We wish to express our gratitude to Danièle Chamereau for taking care of the animals. Mrs. F. Rieuse, Mrs. B. Windsor, Mrs. D. Assan and D. Young prepared the manuscript. This study was supported in part by grants from Ames-Bayer Diagnostics and Novo-Nordisk.

\section{References}

1. Olefsky JM (1981) Insulin resistance and insulin action: an in vitro and in vivo perspective. Diabetes 30:148-162

2. De Fronzo RA, Hendler R, Simonson D (1982) Insulin resistance is a prominent feature of insulin-dependent diabetes. Diabetes 31:795-801

3. Bevilacqua S, Barrett EJ, Smith D et al. (1985) Hepatic and peripheral insulin resistance following streptozotocin- induced insulin deficiency in the dog. Metabolism 34:817825

4. Yki-Jarvinen H, Koivisto V (1986) Natural course of insulin resistance in type one diabetes. N Engl J Med 315:224230

5. Nankervis A, Proietto J, Aitken P, Alford F (1984) Impaired insulin action in newly diagnosed type 1 (insulin dependent) diabetes mellitus. Diabetologia 27:497-503

6. Burcelin R, Eddouks M, Beylot M et al. (1993) Hypersensitivity to insulin during remissions in cyclosporin-treated IDDM patients. Diabetes Care 16:881-888

7. Baudon M, Ferré P, Pénicaud L et al. (1989) Normal insulin sensitivity during the phase of intolerance but insulin resistance at onset of diabetes in the spontaneous diabetic BB rat. Diabetologia 32:839-844

8. Tahiliani AG, McNeill JM (1986) Effects of insulin perfusion and altered glucose concentrations on heart function in 3-day and 6-week diabetic rats. Can J Physiol Pharmacol 64:188-192

9. Koopmans S, De Boer S, Sips H, Radder J, Frolich M, Krans M (1991) Whole body and hepatic insulin action in normal, starved, and diabetic rats. Am J Physiol 260:E825E832

10. Koopmans S, Maassen J, Radder J, Frolich M, Krans M (1992) In vivo insulin responsiveness for glucose uptake and production at euglycaemic and hyperglycemic levels in normal and diabetic rats. Biochim Biophys Acta 1115:230-238

11. Burcelin R, Eddouks M, Kandé J, Assan R, Girard J (1992) Evidence that Glut-2 mRNA and protein concentrations are decreased by hyperinsulinaemia and increased by hyperglycaemia in the liver of diabetic rats. Biochem J 288:675-679

12. Blondel O, Portha B (1989) Early appearance of in vivo insulin resistance in adult streptozotocin-injected rats. Diabet Metab 15:382-387

13. Ferré P, Penicaud L, Hitier Y, Meier M, Girard J (1992) Hypoglycemic effects of a beta-agonist, Ro 16-8714, in streptozotocin-diabetic rats - Decreased hepatic glucose production and increased glucose utilization in oxidative muscles. Metabolism 41:180-183

14. Leturque A, Burnol A-F, Ferré P, Girard J (1984) Pregnancy-induced insulin resistance in the rat: assessment by glucose clamp technique. Am J Physiol 246:E25-E31

15. Ferré P, Leturque A, Burnol A, Penicaud L, Girard (1985) A method to quantify glucose utilization in vivo in skeletal muscle and white adipose tissue of the anaesthetized rat. Biochem J 228:103-110

16. Powell AM, Sherwin RS, Shulman GI (1993) Impaired hormonal responses to hypoglycemia in spontaneously diabetic and recurrently hypoglycemic rats. reversibility and stimulus specificity of the deficits. J Clin Invest 92:2667-2674

17. Girard J, Cuendet GS, Marliss EB, Kervran A, Rieutort M, Assan R (1973) Fuels, hormones and liver metabolism at term and during the early postnatal period in the rat. $\mathrm{J}$ Clin Invest 52:3190-3200

18. Rossetti L, Giaccari A, Barzilai N, Howard H, Sebel G, Hu M (1993) Mechanism by which hyperglycaemia inhibits hepatic glucose production in conscious rats. Implications for the pathophysiology of fasting hyperglycaemia in diabetes. J Clin Invest 92:1126-1134

19. Kerbey AL, Randle PJ, Cooper RH, Whitehouse S, Pask HT, Denton RM (1976) Regulation of pyruvate dehydrogenase in rat heart. Mechanism of regulation of proportions of dephosphorylated and phosphorylated enzyme by oxidation of fatty acids and ketone bodies and of effects of diabetes: role of coenzyme $A$, acetyl-Coenzyme $A$ and re- 
duced oxidized nicotinamide-adenine dinucleotide. Biochem J 154:327-348

20. Hall S, Saunders J, Sonksen P (1979) Glucose and free fatty acid turnover in normal subjects and in diabetic patients before and after insulin treatment. Diabetologia 16:297306

21. Exton J, Corbin J, Harper S (1972) Control of gluconeogenesis in liver. Effects of fasting, diabetes and glucagon on lactate and endogenous metabolism in the perfused rat liver. J Biol Chem 247:4996-5003

22. Wagle S, Ingebretsen W (1975) Studies on gluconeogenesis and ketogenesis in isolated hepatocytes from alloxan diabetic rats. Proc Soc Exp Biol Med 150:786-790

23. Giaccari a, Rossetti L (1992) Predominant role of gluconeogenesis in the hepatic glycogen repletion of diabetic rats. J Clin Invest 89:36-45

24. Shrago E, Lardy H, Nordlie R, Foster D (1963) Metabolic and hormonal control of phosphoenolpyruvate carboxykinase and malic enzyme in rat liver. J Biol Chem 238:3188 3192

25. Cahill GF, Ashmore J (1959) Blood glucose and the liver. Am J Med 26:264-282

26. Beale E, Andreone T, Koch S, Granner M, Granner D (1984) Insulin and glucagon regulate cytosolic phosphoenolpyruvate carboxykinase (GTP) mRNA in rat liver. Diabetes 33:328-332

27. Burchell A, Cain DI (1985) Rat hepatic microsomal glucose 6-phosphatase protein levels are increased in streptozotocin-induced diabetes. Diabetologia 28:852-856

28. Lavoie L, Van De Werve G (1991) Hormone-stimulated glucose production from glycogen in hepatocytes from streptozotocin diabetic rats. Metabolism 40:1031-1036

29. Chiasson J, Liljenquist J, Finger F, Lacy W (1976) Differential sensitivity of glycogenolysis and gluconeogenesis to insulin infusion in dogs. Diabetes 25:283-291

30. Rossetti L., Giaccari A. (1990) Relative contribution of glycogen synthesis and glycolysis to insulin-mediated glucose uptake. A dose response euglycaemic clamp study in normal and diabetic rats. J Clin Invest 85:1785-1792

31. De Fronzo RA, Ferrannini E, Hendler R, Felig P, Wahren J (1983) Regulation of splanchnic and peripheral glucose uptake by insulin and hyperglycaemia in man. Diabetes $32: 35-45$
32. De Fronzo RA (1988) The triumvirate: $\beta$-cell, muscle, liver. A collusion responsible for NIDDM. Diabetes 37:667-687

33. Kahn CR (1978) Insulin resistance, insulin sensitivity and insulin unresponsiveness: a necessary distinction. Metabolism 27:1893-1920

34. Kahn CR, White FM (1988) The insulin receptor and the molecular mechanism of insulin action. J Clin Invest $82: 1151-1156$

35. Burcelin R, Printz RL, Kande J, Assan R, Granner DK, Girard J (1993) Regulation of glucose transporter and hexokinase-II expression in tissues of diabetic rats. Am J Physiol 265:E392-E401

36. Sun X, Rothenberg P, Kahn CR et al. (1991) Structure and function of the insulin receptor substrate IRS-1 defines a unique signal transduction protein. Nature 352:73-77

37. Saad M, Araki E, Miralpeix M, Rothenberg P, White M; Kahn CR (1992) Regulation of insulin receptor substrate1 in liver and muscle of animal models of insulin resistance. J Clin Invest 90:1839-1849

38. Folli F, Saad MJA, Backer JM, Kahn CR (1993) Regulation of phosphatidylinositol 3-kinase activity in liver and muscle of animal models of insulin-resistant and insulin-deficient diabetes mellitus. J Clin Invest 92:1787-1794

39. Kruszynska Y, Home P, Alberti KGMM (1986) In vivo regulation of liver and skeletal muscle glycogen synthase activity by glucose and insulin. Diabetes 35:662-667

40. Kruszynska YT, Home P, Alberti KGMM (1987) Insulin insensitivity and skeletal muscle enzyme activities in response to overinsulinization in the rat. Metabolism 36:281-285

41. Ortmeyer HK, Bodkin NL, Hansen BC (1994) Relationship of skeletal muscle glucose 6-phosphate to glucose disposal rate and glycogen synthase activity in insulin-resistant and non-insulin-dependent diabetic rhesus monkeys. Diabetologia 37:127-133

42. Dent P, Lavoinne A, Nakielny S, Caudwell B, Watt P, Cohen $P$ (1990) The molecular mechanism by which insulin stimulates glycogen synthesis in mammalian skeletal muscle. Nature 345:302-307 